\title{
Assessing the Students and EFL Teachers' Perception and Practice of Active Learning: In Case of Second Year English Language and Literature Students at Kabridahar University
}

\author{
Mulugeta Asnakew, Mebit Bayih, Endeshaw Alemu \\ Department of English Language and Literature, Kabridahar University, Kabridahar, Ethiopia
}

Email address:

Mulugetaasnakew21@gmail.com (M. Asnakew)

\section{To cite this article:}

Mulugeta Asnakew, Mebit Bayih, Endeshaw Alemu. Assessing the Students and EFL Teachers' Perception and Practice of Active Learning: In Case of Second Year English Language and Literature Students at Kabridahar University. International Journal of Education, Culture and Society. Vol. 6, No. 4, 2021, pp. 92-98. doi: 10.11648/j.ijecs.20210604.11

Received: April 23, 2021; Accepted: July 02, 2021; Published: July 13, 2021

\begin{abstract}
The purpose of this study was to investigate English major students' and teachers' perception and practice of active learning. To assess how the perceptions of students influence their practices of active learning and to identify factors affecting the practice of active learning. To conduct the study, qualitative and quantitative method were employed. The study was conducted in Kabridahar University and the data were collected from 16 English major students, and 4 of the English as a foreign language teacher of the University. In the selection of the sample population, simple random sampling was used. And the instrument of data collections: questionnaire, Interview, and Observation were used respectively. And the data were analyzed and presented by using table which were collected through questionnaires from students. The data gathered through class room observation and interview from teachers were presented by statement or by using words. The findings of the study revealed that the implementers of active learning means students' and teachers' have perceived active learning in good way. In spite of their good perceptions, their practices of active learning were low. Among these factors that affect the practice of active learning; lack of students' interest, lack of encouragement, and lack of reference material were the major ones. Finally recommendations were forwarded based on the major findings so to minimize problems encountered, and maximized the implementation of active learning.
\end{abstract}

Keywords: Effective Teaching, Active Learning, Puzzling Situations, EFL

\section{Introduction}

\subsection{Background of the Study}

Effective teaching and learning require the use of different methodologies and strategies to meet the demands of the learners. The traditional passive view of learning involves situations where material is delivered to students using a lecture base format [9].

In contrast, a more modern view of learning is constructivism where students are expected to be active in the learning process by participating in discussions and or collaborative activities [3].

The traditional 'chalk and talk' approach with the students as recipients of knowledge may not be suitable for today's generation. This is why in schools throughout the world there is a movement from learning that is made up of facts to a new model i.e. active-learning which emphasizes understanding, making connections in the world around us, collecting and using information in active manner.

We should think of active-learning first and for most in terms of students being intellectually active. By intellectually active we mean that teachers do not simply expect students to memories and repeat facts [8]. Teachers should expect students to use information critically and analytically [2]. Supporting this has also pointed out that, in active learning the learners have a marked degree of freedom and control over the organization of learning activities. Usually these activities involve problem solving, inquiry and investigational work etc. Similarly, has mentioned that the basic purpose of education is to enable the learners to adapt $\mathrm{him} /$ her in a society, which is full of problems [8]. 
Not only social life is full of problems but there are problems and puzzling situations, which are normal feature of a student's everyday life in school as well. Some researchers were conducted on examine the implementation of active learning, and also on investigate the practice of active learning during EFL, class. However, this kind of work does not done before in this area. Therefore, it is very important encourage students in practice of active learning in school learning in order to solve a problem encountered during teaching and learning process. Thus, this study is to investigate factors that affect the practice on active learning in EFL class [1].

\subsection{Statement of the Problem}

Active learning is the involvement of the students in classroom and outside of the classroom. Active-learning enables them to develop critical thinking skills. [13] explains that active learning is likely to be enjoyed offers opportunity for progress, and thereby fosters Positive attitudes toward the subjects.

Chet et al. remind us that real learning is not memories. Most of what we memorize is lost in hours [4]. In order to retain what has been taught, students must put together what they hear and see into a meaningful whole. In this case, active learning and teaching leads to bring about the expected behavioral change. However, the researcher has selected that assessing English major students and teachers' perception and practice of active learning as a topic of this study. Because, the researcher has observed that the practice of active learning is not satisfactory So by having this in mind, the researcher assessed English major students' and EFL, teachers' perception and practice of active learning at Kabridahar University second year English language and literature in $2013 \mathrm{EC}$.

\subsubsection{General Objective}

The main Purpose of this study is to assess English major students and EFL, teachers' perceptions and practices of active-learning in EFL class at Kabridahar University.

\subsubsection{Specific Objectives}

To achieve the main purpose, the following specific objectives have been set.

1) To assess students and teachers perceptions on activelearning.

2) To investigate how their perceptions influence their classroom practices of active-learning.

3) To explore factors that affects the practice of active learning in EFL class room.

4) To assess how students and teachers actually participate in active learning in EFL classroom.

\subsubsection{Research Questions}

In line with the above specific objectives, the following research questions are formulated.

1) How do teachers and students perceive active learning in EFL class room?

2) How often teachers and students' participate in practice of active learning in their class room?

3) What are the factors that affect students and teachers in practice of active learning in EFL class room?

4) How do teachers and students actually participate in active learning in EFL classroom?

\section{Research Methodology and Design}

This chapter discusses the method employed, research design, procedures of data collection, the instruments used to collect data, the sampling procedure applied, and the method of data analysis.

\subsection{The Research Design}

The main objective of this study is to assess second year English major students' and teachers' perceptions and practice of active learning. To achieve this, the descriptive type of the design was employed. Thus, the researcher utilized both qualitative and quantitative research approach to collect data by using instrument such as questionnaire, interview, and class observation from second year English language major students and teachers of Kabridahar University.

\subsection{The Source of Data and Sampling Technique}

\subsubsection{The Source of Data}

This study was conducted in kabridahar University. Hence the sources of the data are second year English major students and teachers of the University.

\subsubsection{Sample Population}

According to information obtained from the department of English language and literature the total number of second year English major students are 32 and 13 teachers' and they were selected as a sample population in April. 2013 EC for this study.

\subsubsection{Sampling Technique}

In order to get sample populations of this study, the researcher decided to take 16 or $50 \%$ of second year English major students as sample by using simple random sampling techniques. Because, all member of populations equal chances to be selected and to select the sample of teachers the researcher decided to take 4 teachers by simple random sampling. Because, the 4 teachers are teaching the second year English major students, and also they know how students perceive active learning during their EFL class. Therefore, 4 of them were selected.

\subsection{Instrument and Procedure of Data Collection}

\subsubsection{Instrument}

The main instruments of data collections are these three main instruments namely:

Questionnaire, classroom observation, and interview.

\section{(i) Questionnaire}

The questionnaires was prepared by the researcher and completed by second year English major students. The 
questionnaires would have two parts. The first part of the questionnaire was containing close ended and used to gather background of students' in practices of active learning. The second part of the questionnaire was consisted open ended questionnaire to investigate the factors that affect students on practice of active learning [7].

\section{(ii) Classroom Observation}

To obtain more information, observation in the actual class room teaching and learning process used as data gathering instruments. [5] noted that observation is useful to indicate how the lesson is divided in a variety of activities such as: group work, individual work, role-playing, discussion and others. Therefore, to obtain more information the actual classroom observation teaching and learning process was used as data gathering instrument. Which are focusing on teachers' and students' interaction in relation to active learning, classroom facility, teachers' and students' activities during EFL, lesson.

\section{(iii) Interview}

As indicated in [6] interviewing is necessary to get deep feeling, perceptions, values or how people interpret the world around them, and past events that are impossible to replicate. In light of this the researcher had prepared semi-structured interview for four teachers to get valuable information for this work.

\subsubsection{Data Collection Procedures}

The researcher has adopted three steps to collect data for this study.

First, questionnaires were prepared for the selected size of students (respondents) which contain nine questions, and it has two parts. The first part was consisted six questions to get adequate information for this study on students' background on practice of active learning. The second part is containing three open ended questions to get relevant information for this study on factors that affect students on practice of active learning. Second, the researchers collected the data which was distributed for the respondents and from them [10].

Third, after the questionnaires were distributed and collected from the respondents, three semi-structure interview questionnaires was made with second year English teachers to get enough information students perception and the perception on practice of active learning during EFL, classes [11].
Finally the classroom observation was conducted by preparing observation check list on how students and teachers exercised on active learning and their attitude towards to active learning, and how strategies of active learning's were implied.

\subsection{Method of Data Analysis}

The main methods data analysis method(s) are stated bellow

The qualitative and quantitative $\operatorname{method}(\mathrm{s})$ were used to analysis the data obtain from the respondents:

The data obtained from students through questionnaires, and it was analyzed using tables with percentage (quantitative method(s) and each questionnaire and their analysis was reported under the table clearly by using qualitative and quantitative method(s).

The data gathered through class room observation were reported by statement or words clearly without using table. The data gathered through interview were reported in statement or words without using table. Following these conclusions of the finding and recommendation were take place [12].

\section{Data Analyzing, Discussion and Presentation}

In this chapter the data gathered through questionnaires, interview, and observation are discussed, analyzed, and interpreted.

\subsection{Results Related to Students Back Ground in Practice of Active Learning}

The data presented on table 1 indicates that out of 16 respondents, $87.5 \%$ of them responded that their group discussion helps them rather than individual in active learning. The rest $12.5 \%$ of the respondents responded that their group discussions did not help them to be active learner. As can be seen on the table the majority of the respondents witnessed that group discussions are made more active. Thus, based on the response of the majority we can be said that group discussion made more active and learn more than being individual learning.

Table 1. Students' response on group discussion in their EFL class.

\begin{tabular}{|c|c|c|c|c|c|c|c|}
\hline \multirow{3}{*}{ No } & \multirow{3}{*}{ Item } & \multicolumn{6}{|c|}{ Response } \\
\hline & & \multicolumn{2}{|c|}{ YES } & \multicolumn{2}{|l|}{ NO } & \multicolumn{2}{|c|}{ Total } \\
\hline & & No & $\%$ & No & $\%$ & No & $\%$ \\
\hline 1 & $\begin{array}{l}\text { Does group discussion With other students Makes you } \\
\text { active learners Than individual learners }\end{array}$ & 14 & 87.5 & 2 & 12.5 & 16 & 100 \\
\hline
\end{tabular}

Table 2. Students response on practice of active learning enhance their self confidence.

\begin{tabular}{|c|c|c|c|c|c|c|c|}
\hline \multirow{3}{*}{ No } & \multirow{3}{*}{ Item } & \multicolumn{6}{|c|}{ Response } \\
\hline & & \multicolumn{2}{|c|}{ YES } & \multicolumn{2}{|l|}{ NO } & \multicolumn{2}{|c|}{ Total } \\
\hline & & No & $\%$ & No & $\%$ & No & $\%$ \\
\hline 2 & $\begin{array}{l}\text { Do you participate in Practice of active Learning to } \\
\text { Enhance your self Confidence? }\end{array}$ & 12 & 75 & 4 & 25 & 16 & 100 \\
\hline
\end{tabular}


The data presented on the above table indicates that from 16 of the respondents, $75 \%$ of them responded that active learning is enhancing their self-confidence. The rest of the respondents
$25 \%$ of them responded that active learning did not enhance their self-confidence. Thus, based on the majority of the respondents, active learning can be enhancing self-confidence.

Table 3. Student's response on how they perceive practice of active learning during EFL class, and outside of EFL class.

\begin{tabular}{|c|c|c|c|c|c|c|c|c|c|c|c|}
\hline \multirow{3}{*}{ No } & \multirow{3}{*}{ Item } & \multicolumn{10}{|c|}{ Response } \\
\hline & & \multicolumn{2}{|c|}{ bad } & \multicolumn{2}{|c|}{ very bad } & \multicolumn{2}{|c|}{ Good } & \multicolumn{2}{|c|}{ very good } & \multicolumn{2}{|c|}{ Total } \\
\hline & & No & $\%$ & No & $\%$ & No & $\%$ & No & $\%$ & No & $\%$ \\
\hline 3 & $\begin{array}{l}\text { How do you perceive The practice of Active } \\
\text { learning during EFL class and out side Class? }\end{array}$ & 4 & 25 & & & 8 & 50 & 4 & 25 & 16 & 100 \\
\hline
\end{tabular}

As can be seen on table above out $n$ of 16 respondents $50 \%$ of the respondents said that they perceive active learning in good way. And $25 \%$ of the respondents said that we perceive active learning badly. The rest of the respondents
$25 \%$ of the respondents perceive active learning was very good. Thus, based on the majority of the respondents' response the researcher understood that the learners were perceived active learning in good.

Table 4. Students response on how do they participate in practice of active learning.

\begin{tabular}{|c|c|c|c|c|c|c|c|c|c|c|c|}
\hline \multirow{3}{*}{ No } & \multirow{3}{*}{ Item } & \multicolumn{10}{|c|}{ Response } \\
\hline & & \multicolumn{2}{|c|}{ Bad } & \multicolumn{2}{|c|}{ very bad } & \multicolumn{2}{|c|}{ Good } & \multicolumn{2}{|c|}{ very good } & \multicolumn{2}{|c|}{ Total } \\
\hline & & No & $\%$ & No & $\%$ & No & $\%$ & No & $\%$ & No & $\%$ \\
\hline 4 & $\begin{array}{l}\text { How do you participate In practice of } \\
\text { active Learning? }\end{array}$ & & & & & 12 & 75 & 4 & 25 & 16 & 100 \\
\hline
\end{tabular}

As illustrated on the table 4, from 16 respondents $25 \%$ of the respondents responded that they participated in active learning very good. And $75 \%$ of the respondents' practice of active learning was good. Based on the majority of the respondents, the practice of active learning was good.

Table 5. Students' response on how often they participate in debate during EFL class.

\begin{tabular}{|c|c|c|c|c|c|c|c|c|c|c|c|c|c|}
\hline \multirow{3}{*}{ No } & \multirow{3}{*}{ Item } & \multicolumn{12}{|c|}{ Response } \\
\hline & & \multicolumn{2}{|c|}{ Frequently } & \multicolumn{2}{|c|}{ Always } & \multicolumn{2}{|c|}{ Sometimes } & \multicolumn{2}{|c|}{ rare } & \multicolumn{2}{|c|}{ Not at all } & \multicolumn{2}{|c|}{ Total } \\
\hline & & No & $\%$ & No & $\%$ & No & $\%$ & No & $\%$ & No & $\%$ & No & $\%$ \\
\hline 5 & $\begin{array}{l}\text { How often do you Participate in } \\
\text { Debate during your EFL class? }\end{array}$ & & & & & 4 & 25 & 8 & 50 & 4 & 25 & 16 & 100 \\
\hline
\end{tabular}

As shown on the table above, $50 \%$ of the respondents' participation in debate during their EFL, class was rare, and $25 \%$ of the respondents are not at all. The rest of the respondents of $25 \%$ them response was sometimes. Based on the majority of respondents' response, the researcher understood that the participation of students in debate is rare. This indicates that they were not pay attention for debate during their class.

Table 6. Students' response on how often do their teachers encourage them in practice of active learning.

\begin{tabular}{|c|c|c|c|c|c|c|c|c|c|c|c|c|c|}
\hline \multirow{3}{*}{ No } & \multirow{3}{*}{ Item } & \multicolumn{12}{|c|}{ Response } \\
\hline & & \multicolumn{2}{|c|}{ frequently } & \multicolumn{2}{|c|}{ Always } & \multicolumn{2}{|c|}{ sometimes } & \multicolumn{2}{|c|}{ Rare } & \multicolumn{2}{|c|}{ Not at all } & \multicolumn{2}{|c|}{ Total } \\
\hline & & No & $\%$ & No & $\%$ & No & $\%$ & No & $\%$ & No & $\%$ & No & $\%$ \\
\hline 6 & $\begin{array}{l}\text { How often do your Teachers encourage } \\
\text { you In practice of active Learning? }\end{array}$ & & & 4 & 25 & 8 & 50 & 4 & 25 & & & 16 & 100 \\
\hline
\end{tabular}

As depicted on the table above, $50 \%$ of the respondents' responded that the gaining of encouragement from their teachers was sometimes. And $25 \%$ of their response was rare. However, $12.5 \%$ of the respondents' response was always and $12.5 \%$ of their response was not at all. Thus, depends upon the majority of the respondents' response the researcher understood that the encouragement of students towards active learning were sometimes. Thus, students' participation in practice of active learning was not satisfactory.

Table 7. Students' responses on factors that affect their practice of active learning during EFL class.

\begin{tabular}{|c|c|c|c|c|c|c|}
\hline \multirow{3}{*}{ No } & \multirow{3}{*}{ Item } & \multicolumn{5}{|l|}{ Response } \\
\hline & & & \multicolumn{2}{|c|}{ No/ respondents } & \multicolumn{2}{|c|}{ Total } \\
\hline & & & No & $\%$ & No & $\%$ \\
\hline \multirow{5}{*}{7} & \multirow{5}{*}{$\begin{array}{l}\text { What are the factors That affects } \\
\text { your practice Of active learning } \\
\text { During your EFL class? }\end{array}$} & Classroom conditions & 2 & 12.5 & & \\
\hline & & Lack of encouragement & 4 & 25 & & \\
\hline & & From a teacher. & 8 & 50 & & \\
\hline & & Lack of reference materials. & 2 & 12.5 & & \\
\hline & & Lack of confidence & & & 16 & 100 \\
\hline
\end{tabular}


As stated on the above table 7, 25\% of the respondents' response was classroom condition and $12.5 \%$ of them were response Lack of self-confidence, also $50 \%$ of the respondents' response was lack of gaining encouragement from their teachers. And the rest of $12.5 \%$ of the respondents' response was lack of reference. As can be everybody seen fear was the major factors that affect the implementation of active learning. Thus, based on the majority of the respondents fear were the major factors that affect the implementation of active learning.

Table 8. Students' responses on how an improper design of teaching methods affects practice of active learning.

\begin{tabular}{|c|c|c|c|c|c|c|}
\hline \multirow{3}{*}{ No } & \multirow{3}{*}{ Item } & \multicolumn{5}{|l|}{ Response } \\
\hline & & & \multicolumn{2}{|c|}{ No/respondents } & \multicolumn{2}{|c|}{ Total } \\
\hline & & & No & $\%$ & No & $\%$ \\
\hline \multirow{4}{*}{8} & \multirow{4}{*}{$\begin{array}{l}\text { How an improper designed of teaching } \\
\text { methods affect your practice e of active } \\
\text { Learning? }\end{array}$} & Form negative attitude & 8 & 50 & & \\
\hline & & By reduce learns & 4 & 25 & & \\
\hline & & Interest & 4 & 25 & & \\
\hline & & By increase fail & & & 16 & 100 \\
\hline
\end{tabular}

As shown on the table 8 , out of the respondents, $50 \%$ of the respondents said that an improper design of teaching methods affects the practice of active learning is by forming negative attitude towards learning and $37.5 \%$ of respondents said that an improper design of teaching methods affects the practice of active learning is by forming reduce learners interest And the rest $12.5 \%$ of respondents said that an improper design of teaching methods affects the practice of active learning is by increasing fail. Thus, based on the majority of the respondents' an improper design of teaching methods affect the practice of active learning is by forming negative attitude towards learning.

Table 9. Students' response on problems appear if arranging students in group without their ability.

\begin{tabular}{|c|c|c|c|c|c|c|}
\hline \multirow{3}{*}{ No } & \multirow{3}{*}{ Item } & \multicolumn{5}{|l|}{ Response } \\
\hline & & & \multicolumn{2}{|c|}{ No/respondents } & \multicolumn{2}{|c|}{ Total } \\
\hline & & & No & $\%$ & No & $\%$ \\
\hline \multirow{4}{*}{9} & \multirow{4}{*}{$\begin{array}{l}\text { What are the problem occur if The arranging } \\
\text { students without Their ability in Groups } \\
\text { work? }\end{array}$} & Getting low marks & 4 & 25 & & \\
\hline & & Low of learning practice & 8 & 50 & & \\
\hline & & Low of mutual understanding & 4 & 25 & & \\
\hline & & & & & 16 & 100 \\
\hline
\end{tabular}

As illustrated on the above table $9,50 \%$ of the respondents said that the problem appear for arranging students without their ability is low active learning practice and $25 \%$ of the respondents said that the problem appear if the arrangement of students in group discussion without their ability is getting low marks, and the $25 \%$ of the rest of the respondents said that the problem appear if arranging students in group discussion without their ability is low of mutual understanding. Thus, based on the majority of the respondents' response the problem appear if arranging students in group discussion without their ability is low practice of active learning.

\subsection{Data Gathered Through Class Room Observation}

It is known, at Kabridahar University there was only one section of second year English major students. To begin with class room condition there were enough chairs and suitable for students to move from place to place in the class during the their teachers come in to the class who wants to sit in front and for their group discussion during the teachers ordered them to practice of active learning. Also there were enough black board and white board. However, students participation in practice of active learning's were not good due to these factors, fear, interest, and enough reference materials and lack of encouragement, and motivation from teachers during the class. Thus, the researcher understood that these problems were the major cause of low practice of active learning.

Regarding teachers' activities during teaching and learning processes as the researcher observed that all of the teachers were full filled the criteria expected from a teacher. And they were clarifying the lesson, and all of them make clear the lesson before they give explanation. However, some of them were do not give a question to check whether they understood or not.

They write the topic of the lesson on the white board, and they order their students to avoid disturbance. They getting students' attention they clarify the instruction of the lesson until the learners get it right. And also they encourage students to become active participants, and they managing the class for imply active learning. Regarding students activities during the class; students participation in practice of active learning to solve problem is low and they don't taking part peer teaching, and their discussing on issue in group is not satisfactory.

\subsection{Presentations and Analysis of Data Obtained Through Interview}

The analysis of data gathered through interview has also shown that teachers employ on practice of active learning. First, the researcher met the interviews in person and informed them why he wanted them stating the objectives the research. Then winning their willingness addressed to them questions designed to poll their opinion on perception and 
practice of active learning they apply during EFL class i.e. the researcher and the interviewees.

To begin with the question of an interview:

Do you think using active learning has advantage in teaching and learning process?

Regarding question number one, all of the teachers reported that active learning has advantages in the teaching and learning process. They also said active learning makes learners more pleasant and more productive. They went on explaining the technique they apply or use to motivate their students. In this regard three of them said in similar way that they continuously praise, give feedback and make the objective of the lesson clear.

In addition, on teacher said that active learning more advantage. Those advantages are: to produce intelligence generation, to produce self-confidence generation and more generous generation. He also said that I use active learning method during my class.

Thus, the majority of the respondents responses were using active learning has an advantages. Based on this the researcher understood that using active learning has more advantages for teachers to teach their students during their class.

What are the challenges teachers faced in practice of active learning's were; students' attitude towards active learning, means they hate EFL class, lack of reference materials, students fear, and etc. were the challenges they faced during the practice of active learning. Thus, the researcher understood that these challenges faced by teacher during in practice of active learning were difficult. So these types of challenges should be considered as a great issue in practice of active learning.

Researcher "how do you feel about the practicability of active learning in your classroom"

Respondents, I am really interested and believe in the views of active learning. It is exactly the way in which one can learn. I have also taken the training that improves my method of teaching. Student learns more when they are engaged in activities that make them participant. As to its practicability, it is difficult to make it $100 \%$ because of some factors such as interest, reference materials. Another teacher on the other hand put his perception of active learning by saying "It is more of theory than practice." And explained in detail what he feels. The researcher asked the same question: The instructor replied: I think I see active learning differently. Some think as if it is totally practical "TESO" guide line for assessment for example, is theoretically very useful, but practically impossible for a number of reasons like large class size, work load of teachers, lack of teaching material, lack of interest and some complaints of both the teachers and students. The same holds true with active learning implementation. Therefore, provision of teaching materials, budget, encouraging and motivating students should be considered to make it effective. In addition to the above factors, teachers' lack of interest and training on such methodology may affect its practicability. If all these problems are minimized and the teachers accept it willingly active learning may become suitable in different situations.

\subsection{Summary}

The purpose of this study was to investigate English language major students perceptions and practices of active learning in Kabridahar University's EFL class. In order to achieve this purpose, the following specific questions were raised in the study.

1) How do teachers and students perceive active learning in EFL class room?

2) How often teachers and students' participate in practice of active learning in their class room?

3) What are the factors that affect students and teachers in practice of active learning in EFL class room?

4) How do teachers and students actually participate in active learning in EFL classroom?

To gather data required for the study: Questionnaire, interview, observation were employed. Based on the study the following findings are drawn:

The researcher found out that one of the major problems for students in practice of active learning is their fearing of practice in classroom.

As the analyzed data above shown the most common problem of students is lack of encouragement from their teachers due to their interest.

While classroom observation taking place the class does not suitable due to

\section{Conclusion}

The study aims to investigate the English major students' and teachers' perception and practice of active learning in the case of second year. To gather data required for the study: Questionnaire, interview, observation were employed.

Data gathered through these instruments were discussed by using table, percentage, and without table in separated section. Based on the finding of the study, has the following conclusions were drawn. Active learning is practiced sometimes in the EFL classes of the university. The encouragement of students to active learning is one major in the implementation of active learning. But the find of the study has shown that there is lack of encouragement from teachers and lack of reference. Concerning the key factors that affects the implementation of active learning, the following are found to be negatively affecting. Lack of students' motivation, or encouragement, and Lack of enough reference materials.

\section{References}

[1] Aggarwal, J. C. (1996). Principles, methods and Techniques of Teaching New Delhi, S. n. Printers.

[2] Bon well and Elison, A. (2003). Active Learning Creating Excitement in the classroom.

[3] Brad, Hayes (2000) Teacher Centered Instruction vs. Student Centered Instruction: Armuchee High School.

[4] Chet, et al (1993) Promoting Active-learning Strategies for the College Classroom SanFrancisco: Jossey. Base. 
[5] Frazee, M. B. et al (1995) Integrated Teaching Methods: Theory Classroom Approach. A field based Connections New York: Mc Graw Hill Inc.

[6] ICDR, (1999) Teacher Education Hand Book. Addis Abba Fin fine Printing and Publishing.

[7] Kyriacou, C. (1998), Essentials of Teaching Skills (2nd edition), London: Nelson Thorne.

[8] NardosAbebe, (2000), Issues Methods, and Materials in Teaching Primary School Subject Addis Ababa (A. A. U).

[9] Nunan, D (1989) A Client Centered Approach to Teacher Development.
[10] O'Hara. M. and O'Hara, J. A, (1998) Cooperative Learning: A Paradigm for Learning in 21st Century American Secondary Education. Plass, H. (1998) "The Learner- Centered Classroom" Quality Education.

[11] Silberman M, (1996). Active Learning: 101 Strategies to Teach any Subject. Boston: Ally and Bacon.

[12] Smith. E, (1996). The Educator Encyclopedia, Englewood: Prince Hall.

[13] Wilkinson and Bhandarkar (1999). Methodology and Techniques of Social Research, New Delhi: Himalya Publishing House. 